\title{
Esteettinen maisemasuhde ja ympäristövastuu
}

\author{
Tunteen, tiedon ja taidon liitto
}

Yrjö Sepänmaa

\section{Prologi}

\section{Kauneus ja maisema}

Martti Rapola, akateemikko ja suomen kielen professori, julkaisi eläkevaariksi siirryttyään pohdiskeluromaanin Vaarin maisema - elegistä tarinaa (1959), jota hän myöhemmin uudisti ja myös täydensi lisälehdillä nimeltä Omat maisemani (1971). Rapola kirjoittaa ottamassaan roolissa itsestään kolmannessa persoonassa:

\footnotetext{
Mitä on kauneus, mitä luonnonkauneus? Vaari ei ole lukenut estetiikan teoreetikkoja. Mutta hänellä on käsitys, että kauneuttakaan ei sinänsä ole olemassa. Ihminen vain on. Ellei olisi aistivaa ihmistä - ei kauneuttakaan olisi. Jokin ihmisessä oleva järjestää luonnon, joka itsessään on täysin neutraali esteettisessä mielessä, kauniiksi, järjestää rumaksi. Ihmisellä on kyky ja valta täyttää maailma kauniilla ja rumalla. (Rapola 1971, 138.)
}

Järjestäjän herkkyydestä, asenteesta, tiedosta, taidoista ja vastuuntunnosta riippuu lopputulos. Ihminen tulkitsee luonnon järjestystä, mutta myös luo uutta kulttuuria ja sen maisemien esteettistä ilmettä. Näin hän osallistuu ympäristönsä muokkaamiseen ja rakentamiseen.

\section{Maiseman kanssa kasvokkain}

\section{Parisuhde}

Kohtaamisessa, järjestäjän työssä, syntyy vuorovaikutus, osallisuus, joka syvenee kiintymykseksi ja rakkaudeksi. Maisemasuhde on perusta arvostukselle ja huolenpidolle. Näemme maisemassa itsemme, toisen ihmisen, eläimen ja elollistamamme luonnon. Ihminen - yksilönä, lajina, ihmiskuntana - ja maisema ovat liitossa keskenään.

Kuinka hoitaa syntynyttä parisuhdetta? Ihmisten keskinäisten suhteiden hoitamiseen ja ongelmiin antavat neuvoja parisuhdeoppaat. Vastaavia ovat maisemanhoito-oppaat ja kurssit, joita eri järjestöt, yhdistykset ja organisaatiot tuottavat. 
Virpi Suutarin puolidokumentaarinen elokuva Eedenistä pohjoiseen (2014) kuvaa ensiksi parisuhdetta kahden ihmisen välillä, sitten tämän parin suhdetta luontoon, jota edustaa heidän yhdessä muokkaamansa puutarha tai viljelypalsta. Kasveille, kurpitsalle esimerkiksi, puhutaan kuin rakkaalle lapselle, hoiva- ja hellittelykieltä.

\section{Avaruudesta alaspäin}

Maiseman ja ihmisen kohtaamisen tarkastelussa voi lähteä kaukaa: avaruudesta. Maa avaruudesta nähtynä välittyi ensin satelliittien välittämistä valokuvista, sitten astronauttien kuvista ja kertomuksista, joissa korostui Maan kauneus. Kuvien sanottiin näyttäneen keskinäisen riippuvuutemme: elämme rajallisella maapallolla, jonka kohtalo on meidän kohtalomme. Näkemäni korealainen juliste esittää maapallon silmämunana; sitä astronautti katsoo kuin Stanley Kubrickin 2001: Avaruusseikkailussa Hal-tietokoneen silmää.

Maapallokuvista laskeudun valtioiden tasolle. Olavi Vepsäläisen matkailujuliste ja postikortti vuodelta 1948 perustuu tutulle idealle maastamme Suomi-neitona. Piirtäjä muuntaa karttakuvan kansallispukuiseksi nuoreksi naiseksi. Lounaissuomalaisen murrerunoilijan Heli Laaksosen sanoin: "Suami o essumuatone maa." (Hämäläinen 2017, 8.)

Siirryn todellisiin maisemiin. Korkeilta paikoilta avautuu laajoja näköaloja, tyyppiesimerkkinä Ukko-Kolilta Pieliselle aukeava näkymä. Matkailija katselee mietteissään järvelle ja kohtaa kotimaamme kasvot. Suhde on meditatiivinen. Kolin poluilla tietysti kävellään maisemista nauttien - ja talvella lasketellaan sen rinteillä. Esteettistä iloa ja nautintoa saadaan näin mietiskelyn sijasta toiminnasta ja hallitun vaaran tunnusta.

Johdin Kolilla kesäkuussa 1994 järjestettyä ensimmäistä kansainvälistä ympäristöestetiikan konferenssia, jonka nimenä oli Kohtauspaikkana maisema. Se oli tutkijoiden, ympäristöalan ammattilaisten ja ympäristöasioita harrastavien keskinäinen tapaaminen, mutta myös mahdollisuus kohdata yhdessä Kolin maisema. Esitelmistä julkaistiin vuosia myöhemmin kirja, Maiseman kanssa kasvokkain (2007). Tästä inmisen ja maiseman kasvokkaisuudesta otan muutaman esimerkin:

Markku Tano valokuvaa Pielisen maiseman katsojaa Kolin huipulla, panoraamanäkymä edessään (The Maid). Perusasetelma oli jo saksalaisen Caspar David Friedrichin kuuluisassa maalauksessa Vaeltaja sumumeren yllä (Der Wanderer über dem Nebelmeer, 1818). Vaeltaja katsoo maisemaa, maisema katsoo takaisin. Nyt tuo mystifioiva mytologinen ajattelu on kylläkin korvautunut tieteellisellä, mutta perinteinen inhimillistävä puhetapa jatkuu kuvakielessä (Sepänmaa 2014).

Rapola kirjoittaa mainitsemassani omaelämäkerrassaan: "Vaari katselee maisemaa - maisema katselee vaaria. Silmätyksin ovat." (Rapola 1971, 31.) Silmä näyttäytyy tekstissä myöhemminkin: "Nyt sen näkee: maisema on herännyt. Sen aamuvirkku silmä tervehtii etäältä ulapan pinnasta, mihin auringon käsi jo yltää." (Rapola 1971, 119.)

Pessi Rautio, Taide-lehden päätoimittaja tarkastelee Heikki Willamon eläinkuvia: 
Vahvinta Willamon kuvissa on niiden kyky näyttää eläimen katse. Tuo karhu, tuo hirvi on katsonut minuun, minä siihen. Sellainen tilanne on dramaattisimpia mitä ihminen katseella voi saavuttaa, sen sekunnin murto-osan hetken olemme yhtä juurta. (Rautio 2017, 14.)

Samaa lajia ovat Esko Männikön Harmony Sisters -sarjan hevos- ja muut eläinkuvat. Hevosen silmästä heijastuu kuvaaja, joka näkee itsensä hevosen näkemänä - syntyy loputon luuppi, kierre. (Männikkö 2014, 64-71.)

Silmätyksin olemme kyllä - mutta ymmärrämmekö silti toisiamme? Filosofi Ludwig Wittgenstein on todennut, että jos leijona osaisi puhua, emme ymmärtäisi sitä (Wittgenstein 1981, 346). Luonnon kielen ymmärtämistä tutkivat, tukevat ja sääntelevät luonnontieteet, kokemusten ja elämysten ymmärtämistä inmistieteet ja taiteet. Tieteen ja taiteen välissä ovat luontoesseet ja -kuvat. Niissä itse kohde ja sen kokija, kirjoittaja tai kuvaaja tuntemuksineen, ovat yhtä painokkaita kuvauksen aiheita.

\section{Kieli}

Kuvainnollinen, metaforinen kieli inhimillistää maiseman, joka saa näin ihmisen hahmon. Siitä, maisemasta, tulee kaltaisemme ulkonäöltään ja ominaisuuksiltaan. Järvi tai lähde on maiseman kasvojen silmä. Selkä järvellä on niin kuin merelläkin, niemellä nenä tai nokka, joella suu ja polvi, koskella niska, maalla povi ja sydän, metsällä syli.

Kasvoille virittyy ilme - eikä vain yhtä: ne ovat ilmeikkäät. Metsällä on hoitometsien kauneudesta väitelleen Harri Silvennoisen mukaan "tuhat ilmettä" (Silvennoinen 2017, 64). Eri ilmeitä tuottavat vuodenaikojen vaihtelu, säätilan muutokset, kasvukauden vaiheet. Tuo ilme voi olla torjuva, ystävällinen, lempeä, houkutteleva, kutsuva, surullinen... Kesäyö hymyilee, monimielisen vinosti tosin, Ingmar Bergmanin elokuvassa Kesäyön hymyilyä (1955). Lempeä on Aleksis Kiven Seitsemän veljeksen sanoin "kotomaamme koko kuva, sen ystävälliset äidinkasvot".

Kasvot ovat herkät. Niitä hoidetaan - pinnalta kosmetiikan keinoin tai syvältä, tiede- ja tutkimuspohjaisesti. Radikaalia hoitoa ovat kauneusleikkaukset ja esteettinen kirurgia. Ranskalainen performanssitaiteilija Orlan on antanut kasvonsa ja koko ruumiinsa taiteensa materiaaliksi; leikkausten tavoitteena ei hänellä ole itsensä kaunistaminen, pikemmin päinvastoin: ilmaisevuus. Aforisti Lauri Viita puhuu runo- ja proosateoksessaan Suutarikin, suuri viisas vielä kovaotteisemmasta käsittelystä, maiseman kasvojen veistämisestä:

Ei ainoastaan rakennustaito, vaan koko nykyinen teollisuus perustuu veistotaitoon. Konesahat, ilmaporat, räjähteet, kaivukoneet ovat niitä välineitä, joilla Suomen ystävällisiä äidinkasvoja veistetään. Ainoastaan taiteen elävä herkkyys voi nyt ratkaista, kasvaako täällä myös omatunto, vaiko vain maa murenee ja vesi sakenee. (Viita 1961, 92-93.)

Viita-henkisen sitaatin löydän Rapolalta, joka kuvaa Hattelmalan loppuun kaluttua ja sitten uudeksi, toiseksi rakennettua harjuympäristöä:

Sille, että harjun koko kaakkoispää on 'juurta jaksaen' sananmukaisesti kuljetettu pois, eivät Hämeenlinnan tulevat isätkään enää mahda mitään. Jäljellä on suunnaton hauta, johon insinööritaide hitaasti mutta määrätietoisesti pystyttää omien taisteluittensa muistomerkkiä, valtateiden eritasoristeystä kaarteineen ja kierteineen. (Rapola 1971, 226.) 


\section{Vuorovaikutus}

Luonto, maisema, ei vain katso. Se puhuu ja kuulee, vastaa ihmisen tekoihin. Tästä puheesta - niin kuin ilmeistäkin - on syytä ottaa vaarin, sananlaskun sanoin, "sitä kuusta kuuleminen, jonka juurella asunto".

Luonto reagoi ihmisen lailla: raivoten, alistumalla, kuolemalla. Vauriot näkyvät käytöshäiriöinä, pahoinvointina, huonokuntoisuutena. Kumppanuuteen ja luonnon huomioonottoon tähtää ekologinen suunnittelu, jota tukee ekologinen estetiikka. Puhutaan ekosysteemipalveluista: luonto ihmisen, ihminen luonnon palveluksessa. Ihminen hyötyy luonnosta, hyödyntää sitä elinkeinotoiminnassaan, maanviljelyksessä, metsänhoidossa ja kaivostoiminnassa, mutta hakee ja saa siitä myös aineetonta virkistystä ja nautintoa (von Bonsdorff 2002, 92-96).

Luonnosta on ihmisellä aina ollut yrityksen ja erehdyksen tietä saatua käytännön tietoa ja kokemusta, vaikka siihen on sekoittunut uskomuksia ja kuvittelua. Riiteillä, erilaisilla menoilla on pyritty vaikuttamaan luontoon: miellyttämällä ja mielistelemällä, lahjoilla ja lahjuksilla, pyytämällä, lepyttelemällä, anomalla, rukoilemalla. Nyt luontoa ohjaillaan tutkimustiedolla.

\section{Yksi maisema, monta näkymää}

Maisema on perustaltaan aineellinen, fyysinen. Samalla siinä on henkinen, aineeton, ja sellaisena esteettisesti sävyttynyt ulottuvuus. Maisema on ihmisen valinta ja tulkinta, mutta myös kehitelmä. Näin se on ihmiskäden ja -mielen tekoa, suojeltunakin päätöksillämme valittua ja rajattua, ready made, valmisteos. Sitä luodessaan ihminen itsekin muovautuu tekemänsä mukaan; hän tekee tai tulee tehneeksi maiseman omaksi kuvakseen, ääripäinä ihanne- ja irvikuva. Kaunokirjallisuuden henkilöhahmoista nousevat mieleen Oscar Wildelta Dorian Gray ja Edgar Allan Poelta William Wilson.

\section{Monta näkymää yhdessä maisemassa}

Määritelmiä maisemasta on "ainakin 66", toteaa Arthur Lovejoy. Omansa esittävät Tapio Heikkilä ja Risto Timonen teoksensa Suomalainen kansallismaisema (2003) alkusanoissa - ja vaikea tähän on mitään lisätä:

\footnotetext{
Maisema on moniselitteinen sana. Siitä tulee ensiksi mieleen näkymä, jota voidaan tarkastella vaikkapa näköalakalliolta. Maisema voidaan myös purkaa osiinsa: se on paikka tai alue, joka koostuu maaston muodoista, vesistöistä, kasvillisuudesta, pelloista ja rakennuksista. Nuo osaset ovat aina paikalla havainnoitsijasta riippumatta. Luonnon ja ihmiskunnan historia ovat nekin läsnä. Havainto ja sen tulkinta synnyttää ihmismieleen oman maisemansa. Tieto ja tunne syventävät maiseman yksilöllistä kokemista. (Heikkilä \& Timonen 2003, 6.)
}

Maisema kehkeytyy pienestä ja ulottuu suureen, läheltä kauas. Allen Carlson, kanadalainen esteetikko, erottaa yksityiskohtiin keskittyvän objektimallin, taulunomaisen näkymämallin ja tarkastelijan sisäänsä kietovan ympäristömallin (Carlson 1979, 267-275). Tarkastelu voidaan siis kohdentaa vaikka yksittäiseen puuhun tai sen lehteen; näkymän valitsee suuntautunut katse; alue ja ympäristö ovat lukemattomia lähi- ja kaukonäkymiä sisältävänä laajin, puolipallo tai pallo, jonka keskipisteenä olemme. Taivaankannen laki on juuri päämme päällä, missä vain. 
Neljäskin ulottuvuus on: aika. Kaikki on jatkuvassa peittymisen ja sulkeutumisen, kasvun, kuihtumisen ja kulumisen, säätilojen, valon ja pimeyden muutostilassa: järvet ja joet, pellot, metsät, suot, vuoret ja autiomaat, luonnon- ja kulttuurimaisemat, pilvet ja taivas, veden- ja maanalaiset maisemat. Miljöön elementit liikkuvat, vaihtuvat, katoavat ja ilmaantuvat: eläimet, ihmiset, koneet ja laitteet maisemaa hallitseviin tuulivoimaloihin asti. Kaikkeen tähän enenevässä määrin vaikutamme. Mennyt, nykyinen ja tuleva, samoin muistettu, elettävä ja kuviteltu ovat aistittavina ja ajateltavina läsnä.

Ympäristöestetiikan konferensseissa (1994-2009) oli edetty johdannosta, maiseman filosofiasta, keskeisiin maisematyyppeihin: metsään, suohon, veteen, peltoon, kiveen ja taivaaseen. Vuodenajat olisi voinut olla yksi jatkosarjan aihe: kevät, kesä, syksy, talvi. Niitä käsittelee Reino Kalliola Suomen Luonnon Kirja -trilogiansa keskimmäisessä osassa Suomen luonto vuodenaikojen vaihtelussa (1952). WSOY julkaisi Kalliolan teossarjan ensimmäisen osan, Suomen kauniin luonnon, ilmestymisvuonna 1946 teoksen Suomen Talvi, alaotsikkona Runoja ja valokuvia syksystä kevääseen (toimittaneet Yrjö A. Jäntti ja Martti Haavio). Toisen puolivuotiskauden, keväästä syksyyn, kattoi kahta vuotta aikaisempi Suomen Suvi (toimittaneet Yrjö A. Jäntti ja V. I. Mikkonen). Sodan loppuvaiheessa ja heti sen jälkeen haettiin kansakunnan elämän perustaa ja kokoavaa voimaa luonnosta.

Vuodenkiertoon rinnastuu ihmisen elämänkaari Osmo Pekosen toimittamassa kuukausittain, 12-jakoisesti seinäkalenterien tapaan etenevässä Elämän vuodenajat -teoksessa (2005). Korealaisen Kim Ki-Dukin elokuvassa Viisi vuodenaikaa (2003) viides on sukupolvien jatkumo. Spiraalimaisessa kierrossa palataan samalle kohdalle, mutta ei enää samaan paikkaan.

\section{Luonnon-ja kulttuurimaisema}

Luonnonmaisemasta ihminen on poissa - väljemmin tulkittuna ainakin hänen käden- ja jalanjälkensä jää huomaamattomaksi, luonnontilaa myötäileväksi. Voimasuhteet muuttuvat kaiken aikaa. Jos ylläpito lopetetaan, luonto valtaa takaisin kulttuurimaisemat: hakkuuaukot ja viljelemättömät pellot kasvavat umpeen, hylätyt rakennukset luhistuvat ja kokonaiset kylät ja kaupungit kuolevat. Kulttuuriperinnön katoavuuden havainnollistaa Alan Weismanin teos Maailma ilman meitä (2007, suom. 2008), samoin IC-98-ryhmän aidalla "1000 vuodeksi" eristetyn autiotalon pihapiiri. Tarpeeksi etäisyyttä otettaessa nykyinen luonnon ja kulttuurin välinen ero lakkaa näkymästä: Kuusta katsoen kaikki näyttää yhdeltä ja samalta.

Kulttuurimaisema syntyy ja elää tarkastelijan ja tekijän yhteistyöstä. Siinä ovat vastakkain, mutta myös käsikkäin ihminen ja luonto, jonka ihminen mukauttaa tarpeisiinsa. Työ jatkuu jo muokatun jalostamisena yhä uudenlaiseksi, entisen hävittämisenä tulevan tieltä. Tämän seuraamisessa on tehtävää ympäristökritiikille, joka ulottuu yksittäisten kohteiden arvostelusta perustavaan kulttuuri- ja elämäntapakritiikkiin.

Kevyt, luontoa mukaileva kulttuurimaiseman muoto on maalaismaisema kylineen ja pihapiireineen, raskas tiiviiksi rakennettu urbaani miljöö. Kaupunki kaikkineen on olennaisilta osiltaan ihmistyötä, jopa sen viheralueet: virkistysmetsät, puistot ja puutarhat, ympäristötaidekin. Kulttuurin jalanjälki merkitsee luonnon omien mahdollisuuksien ylittämistä - köyhdyttämistä tai rikastamista. Vaikka kulttuuri monessa suhteessa luonnon ja kulttuuriperinnön hävittäjä onkin, se on epäilemättä myös luonnon ja aikaisemman kulttuurin rikastaja. 
Kulttuurimaisema kasvaa ja rakentuu historiallisena kertymänä, suurelta osin sukupolvien perintönä, ilman erityistä suunnitelmaa ja tekijän huolta. Yhä enemmän se on kuitenkin tietoisesti suunniteltua ja säädeltyä. Harkitusti sitä luovat yhdyskunta- ja maisemansuunnittelu, maisema- ja rakennusarkkitehtuuri, puutarha- ja puistotaide. Pienistä kohteista ulotutaan miljöörakentamiseen ja siitä viime kädessä globaalille tasolle. Fantasia- ja paperiarkkitehtuurissa mennään pidemmälle, aina äärirajoille asti: Bruno Taut, itävaltalainen arkkitehti, aloittaa yhden vuorenhuipun, Matterhornin, muotoilusta, siirtyy alppijonoon ja siitä koko Maan kautta tähtisumuun ja galaksien järjestelmiin (Taut 2004/1919).

\section{Arvomaisemat}

Palaan takaisin todellisuuteen ja maan pinnalle. Maiseman huippu- ja kohokohtia ovat paradigmaattiset eli mallimaisemat. Näitä on kahta tyyppiä, yhteisöllisiä ja yksityisiä.

Yhteisölliset, julkiset maisemat ovat taiteen klassikoiden tapaan kulttuurisia kiinnekohtia, joihin tuntemattomampia kohteita suhteutetaan ja verrataan - niin taiteen klassikoillakin on asemansa kenttää jäsentävinä, yleissivistykseen kuuluvina kiinnekohtina. Merkkikohteilla on vahva identiteetti, tunnistettavuus ja tunnettuus.

Suomalaisia julkisia mallimaisemia ovat tämänhetkiset 27 kansallismaisemaa, 40 kansallispuistoa (Hossa uusin), 183 valtakunnallisesti arvokasta maisema-aluetta ja kahdeksan kansallista kaupunkipuistoa (ensimmäinen Hämeenlinnaan 1991, uusin Kuopioon 2017, hankkeita vireillä); epävirallinen asema on käänteentekevien tapahtumien paikoilla, kuten llomantsin taistelupaikoilla.

Yksityisiä, henkilökohtaisesti tärkeitä mieli- ja mielenmaisemia taas ovat kotiseudun maisema ja kotiseutu kaikkineen, omiin elämänkäänteisiin liittyvät tapahtumapaikat ja arjen lähipiiri: ikkuna- ja pihanäkymät, koulu, kesämökki, työpaikka.

\section{Maiseman totaalisuus}

Maiseman ero näkymään on siinä, että näkymä - lähelle tai kauas - havaitaan kerralla, yksiltä jalansijoilta. Maisema on laajempi: alueellisesti ja ajallisesti, aistialueiltaan, kuviteltuna, virtuaalisena, fiktiivisenä. Luonteenomaista maisemalle on juuri totaalisuus, eikä vain lentokoneesta avautuvana vesien, viljelysten, metsien, teiden, kylien ja kaupunkien kirjavana mattona ja mosaiikkina. En voi olla palaamatta Rapolaan, joka kirjoittaa:

\footnotetext{
Maisemasta ei selvitä katselemalla, maisemassa ollaan, eletään, vaelletaan. Tietysti siihenkin pysähdytään, sitäkin katsellaan. Mutta sitä aistitaan muutenkin kuin silmin. Maiseman hallitsevin elementti voi asua vaikkapa näkymättömissä piilevän kosken pauhussa, jatkuvasti seutua hyväilevän tuulen tuoksussa. Maisemaan upotaan kuin Brahmsin tai Franckin sinfoniaan tai Sibeliuksen Tapiolaan. Väittäisinpä, että sen sijaan että näköaloja muistaa kymmenittäin, maisemaa ei elä kuin yhden kunakin kehityskautenaan. Luulen, että ehyesti eletyn lapsuuden maisema syöpyy syvimpään. Mutta kokemiaan maisemia voi muistella kuten näköalojakin. Ehkä niistä voi kertoakin. (Rapola 1971, 224-225.)
}

Maisematilasta rajautuu lukemattomia mahdollisia näkymiä. Näkymä on näköaistin asia, visuaalinen. Maamerkit ja kiintopisteet - kirkontorni, yksinäinen puu, arvorakennus, kalliot ja mäet - kokoavat ja jäsentävät näkymää ja ovat usein myös itse nähtävyyksiä. Muiden 
aistien alueella voisi puhua kuulemasta, tuntemasta, haistamasta, maistamasta. Yhdessä ne ovat moniaistisen maiseman osatekijöitä.

Alueet laajenevat maisemamaakunniksi, ja maakunnallinen identiteetti syntyy maisemista osatekijöinään murre, tavat, elinkeinot. Paikalliskirjallisuus, kuvataiteet ja maakuntalaulut nostavat esiin sitä, mikä kussakin koetaan arvokkaimmaksi ja omimmaksi.

\section{Aineeton, henkinen maisema: maisemakuva}

Geologiselle perustalle rakentuu ihmisen muokkaama ja aikaansaama. Tähän kaikkeen tarkastelu kohdistuu, siihen syntyy kosketus, tuntuma. Tunne maisema -näyttelykirja, jonka Suomen Museoliitto palkitsi vuoden 2012 museojulkaisuna, toi esiin tiedon ja ymmärryksen lisäksi tunnun ja tuntuman. Kirjan nimi on tarkoituksellisen moniselitteinen kehottaessaan maisemaa koskevan tiedon hankkimiseen, tunnekosketus hyväksyen. Emotionaalisen koskettavuuden rinnalla on fyysinen kosketus, tuntoaistin tunto, se miten tuulenvireen aistii iholla tai sammalen upottavuuden jalkapohjissa.

Konkreettinen ja abstrakti on maisemakuvakin, kuva maisemasta. Se on visuaalinen maalauksena tai valokuvana, mutta abstrakti käsityksenä ja näkemyksenä. Maisemakuva vertautuu ihmis- ja henkilökuvaan. Näkyvää on kuluva hetki, näkymätöntä mennyt ja tuleva. Symboliset, vertauskuvalliset ulottuvuudet ovat aineettomia nekin, kuin varjot ja heijastukset. Aineeton, silti toden tuntuinen on virtuaalinen ja fiktiivinen maisema, välimuotona digitaalinen lisätty todellisuus.

Olavi Paavolainen puhui ajattelevasta maisemasta. Aunus Harmaasilmäksi hän sen nimesi - henkilöllisti etu- ja sukunimeä myöten. Maisemaa on ilmapiiri, atmosfääri, "paikan henki", tunnelma, mielentila - sodanaikaisen Aunuksen "hyrisevän hämärän, kodikkuuden ja viisauden väri", yhtenäinen harmaus (Paavolainen 2012, 136).

Mikä olisi nykyään samanlaisen levollisen kotoisuuden miljöö? - Varmaankin kotiseutu, sen tuttu, omaksi koettu elämäntapa ja elämänpiiri. Sulevi J. Riukulehto puhuu henkisestä ja toiminnallisesta ympäristöstä kotiseutuna: "Luonnonympäristö ja rakennettu ympäristö jättävät jokaiseen pysyviä jälkiä. Tärkeintä kotiseutua on kuitenkin henkinen ja toiminnallinen ympäristömme. Miten syödään, puhutaan, pukeudutaan, käyttäydytään, miten meillä päin tavataan ajatella ja toimia eri tilanteissa." (Riukulehto 2012.)

Matti Mäkelä, IImajoella syntynyt ja kasvanut kirjailija, puolestaan kirjoittaa murteesta sydämen kielenä, kotimurteellaan:

Murre, son piilopirtti, son joulu ja juhannus meirän syrämmes. Son niinku istuus kesäsyrännä kannonpääs nevan keskellä saares, ku suopursu tuloo väkevästi nenähän, kevyt kesätuuli puhalteloo pairan alle kainaloohin ja kalavehes on heleppo hengittää. (Mäkelä 2001, 12.)

\section{Maisemakokemus}

Maisemassa, esimerkiksi metsässä, ollaan fyysisesti ja henkisesti, sisällä tai ulkona, ympäröitynä ja piiritettynä. Perinteisesti on pidetty esteettistä välimatkaa, jolla tarkoitetaan fyysistä, mutta myös henkistä etäisyyttä, analyytikon viileää asennetta. Vaihtoehtoisesti 
puhutaan kietoutumisesta, osaksi tulemisesta, lämpimästä, jopa palavasta, kuuman kiihkeästä osallisuudesta.

Tulen takaisin alkutilanteeseen, esimerkkiini Pielisen katsojasta Ukko-Kolilla. Vaeltaja on fyysisesti näkymänsä, maisemansa reunalla, mutta myös sen sisällä, keskipisteenä. Tarkastelupaikaltaan hän kohdistaa huomionsa edessään olevaan järvinäkymään.

Tällainen sektorinäkymä on ihmisellä enimmillään 180 astetta. Käytännössä erilaiset näkemäesteet rajaavat sen kapeammaksi tai jakavat kaistaleiksi. Näin syntyy puiden ja erilaisten rakennelmien kehystämä maisemataulu. Sosiaalinen sopimus sanoo, ettei taulusta jäädä katsomaan selkäpuolta. Kolin huipulta voidaan tietenkin katsoa taaksekin, mutta se on oletuksenvastainen valinta. Taulunomaisin on mikä tahansa ikkunanäkymä: "Maatila on mitä kauneimmalla paikalla niemennokassa. Tuvassa on ikkunoita kolmeen ilmansuuntaan. 'Jokaisessa ikkunassa maisema on erilainen, ja se muuttuu jatkuvasti."' (Hiltunen 2017, 126.)

Kaikkea nähtävää ei aktiivisesti katsota. Valikoiva näkeminen sulkee häiritsevän pois; Kolin hiihtohissit ja paljaat laskettelurinteet halutaan unohtaa. Puolalaiselle esteetikolle Janina Makotalle sulkeistettavaa oli maastossa kulkeva puhelin- tai sähkölinja (Makota 1984/1976). Aina tämä poisto ei onnistu. Valokuvaaja Matti A. Pitkänen valitteli, kuinka vaikeaa alkoi olla löytää kuvauskohteiksi ehjiä, häiriöttömiä näkymiä (Pitkänen 1975, 462).

Puolipallon keskipisteenä ollaan Pohjanmaan lakeuksilla, aavalla suolla ja avomerellä. Näkötornista avautuu 360 asteen skaala - näin vesitornista llomantsissa, Puijon tornista Kuopiossa tai miltä tahansa korkealta lakealta paikalta.

Laajin on kokonainen pallo, jota lähetään näkötornissa - näkymä myös alaspäin. Alasuunta korostuu lennossa: yläpuolella taivaankansi, alla aukkoinen pilvipeite ja maanpinta. Kuitenkin selvimpänä pallon vaikutelma syntyy toden ja virtuaalisen yhdistelmänä: tähtitaivas ja sen peilikuva tyynessä vedessä. Katselin tuota toden ja kuvajaisen ykseyttä Kalevalaseuran Nehvon vartion laiturilta llomantsissa. Syntyi vahva illuusio keskipisteessä olemisesta, kun jalkojen edessä ja alla oli tähtitaivaan mittaamaton virtuaalinen syvyys. Kuvittelin tyhjyyteen astumista tietäen, että vettä olisi tuskin metriäkään: ylevyys saisi koomisen lopun.

\section{Oma ja vieras maisema}

"Oletko näissä maisemissa, 'täällä'?", kysytään usein. Voin olla paikalla, mutta ajatukset ja mieli poissaolevana, tai olen läsnä, ruumiiltani ja mieleltäni. Joskus olen toivottu vieras, toisinaan tunkeilija. Kulttuurinen omiminen merkitsee väkivaltaista tuloa toisen reviirille, myös toiselle kuuluvan ja merkityksellisen ottamista väkisin. Paavolainen puhuu tämänpäiväisesti ideoiden omistelemisesta $(2012,18)$. Omaan on tunnesidos, jota tunkeileva käytös loukkaa.

Jyrki Vainonen, Suomen Kirjailijaliiton nykyinen puheenjohtaja, käsittelee esseessään "Askelia kotiseudulla" läsnä- ja poissaoloa, niin fyysistä kuin henkistäkin: ollaan, lähdetään tai tullaan. Vainonen leikittelee suomen kielen sisäpaikallissijojen (inessiivi, elatiivi, illatiivi) ja ulkopaikallissijojen (adessiivi, ablatiivi, allatiivi) suhteella. Vielä kouluaikanani opittiin näiden suomenkieliset nimet: sisäolento, sisäeranto ja sisätulento, ulko-olento, ulkoeranto, ja ulkotulento. 
Sijamuotojen nimet tahallisesti väärinymmärtäen, siten ne ruumiillistaen ja henkilöllistäen, Vainonen kuvaa käyntiään entisellä kotiseudullaan. Hänestä, entisestä sisäolennosta, on tullut ulko-olento:

Kun palaan kotiseudulle, voin kävellä samoilla paikoilla kuin menneisyydessä, mutta samoissa paikoissa kuljeskelu ei onnistu. Siinä missä lapsuuden kokemus, ensi- ja ainutkertainen, sai sijamuodokseen inessiivin eli sisäolennon, siinä uusi, toistava kokemus joutuu tyytymään adessiiviin eli ulko-olentoon. Kun kerran sisältä päin eletty kokemus yritetään elää uudelleen, ovet sulkeutuvat, portit paukahtavat kiinni, lukot helähtävät; meidät pakotetaan ulkokohtaiseen kokemukseen.

Minusta on tullut ulkopuolinen, ulko-olento, suhteessa varhaisiin kokemuksiini. Paikoissa käveleminen on muuttunut paikoilla kävelemiseksi, inessiivi adessiiviksi. Se ilmaisee sijaintia jonkin päällä, jossain pinnalla tai jonkin lähellä, ei enää jonkin sisällä. Ajan kuluminen, joka sekä synnyttää muistot että ilmentää niitä, estää minua enää olemasta sisäolento.

Minut on tylysti ulkoistettu menneestä elämästäni. (Vainonen 2014, 32.)

Vainonen jatkaa seuraavalla sivulla:

Kun kiipeän Rautakorven mäelle ja katselen maisemia kallion laelta, ehkä sadan metrin korkeudesta, katselen maisemaa, josta on tullut minulle vieras. En ole siellä. Kävelen samoilla paikoilla, en samoissa paikoissa.

Maisemansa reunalla ja ulkopuolella on myös Marja-Liisa Vartion kertomuksen "Alma käy kotona" nimihenkilö kotikylässä käydessään:

[...] ja hän pysähtyi, katsoi suoraan kotitaloaan kohti, katsoi talon auringonmuotoista vintinikkunaa ja vasta nyt kuin hämmästyen näki että se oli tehty auringonmuotoiseksi. Kun on irti kaikesta, näkee millaista se on ollut, eikä se tuottanut tuskaa hänelle - hän ihmetteli sitä että saattoi seisoa näin ja katsella tuotakin taloa kuin vierasta, kysyen mikä se oli ja mikä olen minä, mitä on tapahtunut minulle kun en tuotakaan sure. (Vartio 1968, 151.)

Almaksi tunnen itseni, kun ajattelen kotiseutuani, synnyin- ja kasvukuntaani Alavutta. Käyn siellä satunnaisesti asuttuani muualla puoli vuosisataa. Välittäminen ja välinpitämättömyys, tunne ja tunteettomuus, voimattomuus, lämmin ja kylmä vaihtelevat. Mennyt maisema limittyy olevan kanssa, tuleva hahmottuu kehityslinjoista. Kaksi maisemaa asettuu päällekkäin, kouluaikainen ja nykyinen: talot, joissa asuu minulle tuntemattomia muistamieni sijasta, ja pelloilla etenee omakoti- ja rivitalojen rintama. (Sepänmaa 2017/2012.)

Oma Joensuun kokemukseni nykyään, yli 20 vuoden asumisen jälkeen, on kulkenut asettumisesta, oppimisesta, kiintymyksestä mukanaoloon, siitä irrottautumiseen, vieroittumisoireisiin ja vieraantumiseen, edessä olevaan hyvästelyyn, säilyviin muistikuviin, unohdukseen. Käykö periksiantajalle niin kuin Pentti Linkolalle, joka Helsingin Sanomien haastattelussa (17.8.2017) toteaa: "Vanhuudesta on se hyöty, että tunne-elämä laimistuu. Nuorempana olisin ollut surullisempi kuin mitä nyt olen. En tunne enää tuskaa, ainoastaan pysyvää alakuloa." (Vainio 2017, B 2.) 


\section{Etiikka, vastuu}

Ympäristöestetiikan ja -etiikan välillä on yhteys: esteettinen on merkittävä eettisen toiminnan peruste. Kauneudesta tulee suojelun motiivi: on vastuu siitä, mitä arvostaa. Vastuunotto näkyy rakkautena, huolena ja huolenpitona, kunnioittavana käytöksenä. Reino Kalliola otsikoi puhe- ja kirjoitusvalikoimansa lähes 50 luonnonystävävuodeltaan (1930-1977) tunneyhteyttä ja mieltä painavaa vastuunkantoa korostaen: Luonto sydämellä (1977).

Pelkäksi mielipideasiaksi ajateltua kauneutta olisi voitava suojella suoraan, ei taktista kiertotietä käyttäen uhanalaiseen kasvi- tai eläinlajiin turvautuen, oli se sitten aina käyttökelpoinen liito-orava tai harvan tietämä lahokaviosammal (Varmavuori 2017). Jo Arto Kytöhonka, kirjailija ja kriitikko, neuvoi kyynisesti kiertotielle luonnonkauniiden soraharjujen suojelussa - kauneuteen vetoaminen kun käännettiin pitämiskysymykseksi, kun taas kasvin tai eläimen olemassaolo oli näytettävissä - yksinkertainen tosiasia. Estetiikalle on nyt haaste kehittää pitäviä perusteita ja argumentteja kauneuden osoittamiseen; tarvitaan myös tehoavaa, emotionaalisesti koskettavaa retoriikkaa näkemysten puolustamiseksi ja sanoman levittämiseksi.

Omistussuhteista riippumatta maisema on julkishyödyke, yhteistä hyvää. Se kuuluu kaikille, mutta kaikki voivat sen menettää aivan kuin saarijärveläiset Tapperin veljekset koskensa tai vaari hämäläisen maisemansa. Säilyminen edellyttää aktiviteettia, toimia arvokkaaksi katsotun puolesta: perinnemaisemien ylläpitoa, rakennusten korjaamista yhteistoimin ja yksityisesti; adoptiota ja kummitoimintaakin on ratkaisuksi kehitetty. Merkitsevin pitkän päälle on säästeliäs elämäntapa, jota esimerkiksi kohtuusliike korostaa. Taustatukena on ympäristövalistus, asennekasvatus ja ympäristösivistys, viime kädessä laki sanktioineen.

\section{Positiivinen ja kriittinen estetiikka}

Suhde ympäristöön voi olla neljänlainen: tunneperäisen lämmin (mietiskelevä, meditatiivinen, emotionaalinen, elämyksellinen), järkiperäisen viileä (älyllinen, tiedollinen, tieteellinen), huomaamattoman tai välinpitämättömän neutraali (tutkijan tai suunnittelijan asiakeskeinen suhde) tai avoimen hylkivä, torjuva.

Poikkeuksellisen kauniit maisemat koskettavat syvästi, jopa kohtalokkain seurauksin. Stendhalin syndrooma valtasi Caprilla Italiassa Juhani Ahon, joka halusi "kuolla kauneudessa", "nakkautua" alas mereen (Aho 1921, 268-269). Paolo Sorrentinon ohjaaman Suuri kauneus -elokuvan korealainen turisti lyyhistyy kuolleena maahan videoidessaan Rooman näkymiä. Imatrankoski ja Niagara ovat puoleensavetäviä - sananmukaisesti ja kuvainnollisesti.

Faabeleitten maailmasta löytyy mielikuvitusta kiehtovia esimerkkejä. Marko Leppänen toistaa kertomukset kaivosponista ja sammakosta, jotka kauneus tappoi:

Joskus on väitetty, että kaivosponi saattoi kuolla sydänkohtaukseen nähdessään taas taivaan tai kaukaisen horisontin - niin tajuntaa räjäyttävä oli sen laajuus suljettuun ympäristöön tottuneelle.

Kaivossa asuva sammakko lähti toisen mukaan ja kun se lopulta näki valtameren, kuoli se välittömästi sydänkohtaukseen (rajumman version mukaan sen pää räjähti). (Leppänen 2012.) 
Arvot ja makukäsitykset kyllä eroavat, muodit vaihtuvat; on myös järjestelmien sisäisiä ristiriitoja ja epäloogisuutta kriteerien soveltamisessa, päättämättömyyttäkin. Hierarkia on ehkä hyvinkin erilainen asiantuntijalle ja maallikolle. Voi olettaa, että maisemaan liittyvä tieto geologinen, kulttuurihistoriallinen, tyylejä koskeva ja omiin kokemuksiin ja havaintoihin perustuva - antaa joskus välttämätöntä ja tukevaa perustaa arvokäsityksille. On siis maisemiin liittyvää asiantuntemusta. Kaiken nähnyt kriitikko etsii yhä uutta ja hätkähdyttävää, maallikko tyytyy helpommin tuttuun ja turvalliseen ympäristöviihteeseen.

Luonnonmaisema pyritään ymmärtämään ja hyväksymään annettuna; kulttuurimaisemaa arvostellaan kysyen, miten sen voisi tehdä paremmaksi. Joskus riittää ymmärtävä asenne. Kotiseudun Reino Kalliola rinnastaa omiin vanhempiin: kotiseutu ja vanhemmat, isä ja äiti, hyväksytään annettuina. Tosiasiassa näitäkin arvostellaan, mutta taustalla on, harvinaisin poikkeuksin, peruskunnioitus.

Vanhalla ja vakiintuneella on taipumus muuttua luonnontilan kaltaisesti arvostetuksi. Tarvitaan kyllä jokin perushyvyys, minimitaso, jotta kohdetta voisi mielekkäästi edes sanoa maisemaksi tai taideteokseksi. Arvon mittapuiksi on tarjottu esimerkiksi yhtenäisyyttä, kompleksisuutta, intensiteettiä, mutta käytännössä nämä voivat toteutua yllättävin ja monitulkintaisin tavoin.

Poikkeavan näkökohdan luonnon (maailman) täydellisyyteen tarjoaa Juha Hurme Sielunmetsä-elokuvan (2017) lopussa miettiessään: "Maailma on ressukka. Siksi sitä pitää suojella, jotta siitä vielä tulisi jotakin, ei siksi että se olisi niin täydellinen." Kaikki on Hurmeen mielestä "vähän vinksallaan". Ihmiselle jää suuri kasvatustehtävä. Uskoa ja luottamusta humanismin voimaan on siinä, että ihmisen talonpidossa maailma kehittyisi ja sivistyisi.

\section{Ympäristöestetiikka - teoreettisesta soveltavaan}

Estetiikasta puhutaan kolmessa merkityksessä: ensiksi kauneuden etusijalle asettavana elämänasenteena, toiseksi toimintaa ohjaavana ohjelmana eli manifestina ja kolmanneksi akateemisena filosofisena tutkimuksena, kohteinaan taide, kauneus ja kritiikki.

Elämänasenteessa on kysymys esteettisten arvojen korostamisesta, joskus estetismiksi kärjistyneenä; ohjelmana on kysymys jonkin makujärjestelmän tai tyylin manifestinomaisesta ajamisesta; filosofinen tutkimus analysoi esteettisiä ilmiöitä ja niistä käytettävää kieltä.

Päätin estetiikan alan väitöskirjani The Beauty of Environment vuonna 1986 kysymykseen passiivisesta ja aktiivisesta estetiikasta. Katsoin siihenastisen työni edustavan passiivista muotoa, ulkopuolelta tarkkailevaa, kantaaottamatonta metakritiikkiä. Tämä keskittyi taiteen ja ympäristön sijasta taide- ja ympäristöpuheeseen; analysoin kuvauksen, tulkinnan ja arvottamisen kieltä ja tarkastelin kielenkäytön strategioita ja vaikuttavuutta, retoriikkaa.

Sitten oli aktiivisen estetiikan aika. Edeltäjäkään, passiivinen, ei ollut turhaa työtä - se muodosti perustan aktiiviselle, joka merkitsee esteettisen asiantuntijuuden käyttöönottoa, toimintaan vaikuttavaa soveltavaa tutkimusta, konsultointia. Yksityishenkilöille tarjotaan henkilökohtaista opastusta, keskusteluapua mieltä askarruttavissa kysymyksissä. Tavoitteena on ajattelun ja argumentoinnin selkeyttäminen, vastausvaihtoehtojen esiintuonti, kunkin oman ajattelun tukeminen. Käytännön esteetikko on henkilökohtainen valmentaja 
tai ympäristöluotsin tyyppinen keskustelukumppani. Organisaatioille ja järjestöille voidaan antaa lausuntoja maisemansuunnittelussa, maisema-arkkitehtuurissa, suojelussa.

\section{Tavoite: viisi e:tä yhteen}

Päätöksiä tehdään luonnonmaisemia, mutta myös kulttuurimaisemia säilytettäessä ja niitä muutettaessa. Metsänhoito, maanviljelys ja kaikenlainen rakentaminen merkitsevät muutoksia. Tärkeää on etukäteisarvostelu, ateljeekritiikki, vielä toteuttamattoman tarkastelu piirustuksista, havainnekuvista, pienoismalleista ja videoista käsin, jotta suunnitelmia voitaisiin ennen lopullista toteuttamista korjata ja kehittää. Tämä oli yksi tavoite VTT:ssä toteutetussa ESSU-hankkeessa (Esteettisesti ja laadullisesti korkeatasoinen fyysinen ympäristö ja uudet suunnittelutekniikat). Nähtiin, että oli kehitettävä välineet siihen, miten eri osapuolten näkökohdat ja kannat saadaan esille. Tekijä kuulee - ja oletettavasti ottaa varteen - toiveet ja vaatimukset. Uskottiin, että ihmisen - yksilön ja yhteiskunnan - päätöksiin ja tekemisiin voidaan vaikuttaa.

Tiedon ja asenteiden tason tavoitteena on ympäristösivistys ja -viisaus: hyvät tavat, toisen huomioonotto, kohtuus, joustavuus. Tähän kuuluu eri arvojen keskinäinen punninta. Esteettiset arvot ovat yksi arvolaji, mutta myös arvojen suhdeverkostolla on esteettisiä ominaisuuksia: tasapainoista kokonaisuutta voi sanoa esteettiseksi sitäkin.

Päätöksenteossa joudutaan tunnustamaan ja ottamaan huomioon etunäkökohdat, arvoristiriidat, konfliktit: mitä menetetään, mitä voitetaan milläkin ratkaisulla. Maisemansuojelussa ja -suunnittelussa, miljöönrakentamisessa, esinekulttuurissa ja kaikessa toiminnassa on mukana viisi e:tä, viidet arvot: esteettiset, emotionaaliset (empaattiset), eettiset, ekologiset ja ekonomiset. Näitä yhteen sovitettaessa, optimitilaa haettaessa, on pakko tehdä kompromisseja kokonaishyvän saavuttamiseksi.

Lopetan muutamaan esimerkkiin arvojen yhteensovittamisen ainakin kohtuullisesta onnistumisesta, mutta myös "jäätyneistä konflikteista":

Liikenneturvallisuus ja taiteelliset arvot törmäsivät 1980-luvulla Punkaharjun Retretin seisaketta koskevassa keskustelussa. Olavi Lanun Siirtolohkare (1987) oli isokokoinen ympäristötaideteos, mutta samalla myös seisakkeen suojakatos junamatkustajille - ja varsinkin uutena liikenteestä huomion vievä hämmästelyn aihe viereisen tien autoilijoille. Teos on saanut jäädä paikalleen ja siihen on totuttu.

Helsingin Kruunusiltojen - Kruunuvuoren ja Korkeasaaren - suunnittelukilpailun tuomariston arviointi kilpailutöistä sisälsi kolme kriteeriryhmää: kestävyys, käytettävyys ja esteettisyys. Jokaiselta osa-alueelta oli oma arviointiryhmänsä, ja tulokset yhdistettiin lopuksi. Esteettisyydellä tarkoitettiin tässä (1) uutta maamerkkimäistä elementtiä (näkyvyys) tai (2) sopeutumista vähin äänin (näkymättömyys). Esteettisyyden asiantuntijoina olivat muotoilujohtaja, rakennusarkkitehti ja maisema-arkkitehti. (Kruunusillat 2013.) Sillat rakennettiin ja lopputulokseen ollaan yleisesti tyytyväisiä.

Pitkäaikainen kiistakohde on Helsingissä ollut Keskuspuisto ja erityisesti sen kaupunginpuoleinen pää, Töölönlahden alue, joka ulottuu puistona nykyiseen Kiasmaan asti. Alueen tämänhetkinen puisto on tilapäiseksi tarkoitettu halpaversio. Alueeseen, laajemmin 
pääkaupungista käytävään keskusteluun ja yleisemmin ympäristönsuunnitteluun otti kantaa latvialaisen Kristaps Gelziksen Eco yard 2000 -niminen ympäristötaideteos, jolla oli selventävä alaotsikko, "100 m2 aidattua maata suojattu kaupungistumiselta". Lähes 20 vuotta (1995-2014) se kävi taisteluaan, mutta tuli sitten laajenevan rakentamisen jyräämäksi. Eräänlaiseksi jatkoksi tulkitsen Ars 17:n Ilja Karilammen Pääkaupunki-tilateoksen osan, graffitimaisen tekstin "Jatka taistelua" - taistelevaa humanismia! Epätietoisuus alueen kohtalosta jatkuu.

Kun Suomen Kuvalehti haki kesällä 2017 uusia kansallismaisemia, esitin puolestani Kiasman kuudennesta kerroksesta Töölönlahdelle avautuvaa ja symbolisesti Lappiin ulottuvaa maisemaa (Kylänpää 2017, 36-37). Se on jännitteinen vanhan ja uuden, olemassa olevan ja suunnitellun kohtaamiskenttä - tuskin koskaan valmis.

Helsinkiin on valmisteltu kansallista kaupunkipuistoa, joka toteutunee. Ristiriitaiset tavoitteet ja päättämättömyys ovat myös Joensuussa olleet esteenä kaupunkipuiston etenemiselle. Keskeisillä paikoilla on säilynyt takapihan luonne, parkki- ja varastointipaikka siinä missä karjalaiskylän perinteen mukaisesti pitäisi olla etupiha, näkymä ja yhteys joelle. Tilanne on sama Helsingissä kaatuneen Guggenheim-museohankkeen merenrantapaikalla. Museosuunnitelman tultua jo tyrmätyksi ilmaantui julistekampanja. Valokuvaa parkkialueena toimivasta asvalttikentästä peitti turhautumisesta kertova teksti: "On se niin nätti. Mitä sitä taiteella pilaamaan." Kummankin - Joensuun ja Helsingin - tilanne on jäätynyt konflikti.

\section{Postscript/Jälkikirjoitus}

"Emme tarvitse uusia maisemia, tarvitsemme uudet silmät." Tämä hieman muotoiltu lausuma Marcel Proustilta oli rakennustyömaan suoja-aitaan maalattuna Töölönlahden alueella.

Uusia maisemia emme ehkä tarvitse, olemassa olevissakin on näkemistä ja kokemista. Silti kaipaamme, odotamme dynamiikkaa (ilman dynamiittia): syntyvää, nousevaa, kasvavaa tai edes pääsyä vielä käymättömiin paikkoihin.

Emme ehkä tarvitse uusia silmiäkään, mutta uudet silmälasit voisivat auttaa näkemään kirkkaammin, tarkemmin ja kauemmaksi. Muutettavat muuttaen: citius, altius, fortius eli nopeammin, korkeammalle, rohkeammin.

\section{Kirjallisuus}

Aho, Juhani 1921: Kuvaus Kaprista. Kootut teokset. VI nidos. Porvoo: WSOY. 266-273.

Bonsdorff, Pauline von 2002: Maisema elintilana: Kulttuuri, luonto ja estetiikka. - Pitkäranta, Inkeri \& Esko Rahikainen (toim.), Suomalainen maisema. Maisemantutkimuksen näkökulmia. Helsinki: Helsingin yliopiston kirjasto-Suomen kansalliskirjasto. 92-96.

Carlson, Allen 1979: Appreciation and the Natural Environment. - The Journal of Aesthetics and Art Criticism 37(3): 267-275. 
Heikkilä, Tapio 2007: Visuaalinen maisemaseuranta. Kulttuurimaiseman muutosten valokuvadokumentointi. Helsinki: Kustannusosakeyhtiö Musta Taide ja Taideteollinen korkeakoulu.

Heikkilä, Tapio \& Risto Timonen 2003: Suomalainen kansallismaisema. Helsinki: Otava.

Heinänen, Seija, Pauline von Bonsdorff \& Virpi Kaukio (toim.) 2012: Tunne maisema. Helsinki: Jyväskylän Taidemuseo \& Maahenki.

Hiltunen, Eija Irene 2017: Ilomantsi - ihan syrjässä! Ilomantsi.

Hämäläinen, Karo 2017: Kotomaamme koko kuva. Kirja. Messulehti 2017. Helsingin Kirjamessut. 8-9.

Inha, I. K. 1909: Suomen maisemia, Näkemänsä mukaan kuvaillut I. K. Inha. Helsinki: WSOY.

Jäntti, Y. A. \& Martti Haavio (toim.) 1946: Suomen Talvi. Runoja ja valokuvia syksystä kevääseen. Porvoo: WSOY.

Jäntti, Yrjö A. \& V. I. Mikkonen (toim.) 1944: Suomen Suvi. Runoja ja valokuvia keväästä syksyyn. Porvoo: WSOY.

Kalliola, Reino 1977: Luonto sydämellä. Kirjoitelmia ja puheita 1930-1977. Porvoo-HelsinkiJuva:WSOY.

Kruunusillat 2013. Kruunusillat-suunnittelukilpailu, Arviointipöytäkirja 7.6.2013. Helsinki: Helsingin kaupunki, Rakennusvirasto.

Kylänpää, Riitta 2017: Sieltä näkee kauas. - Suomen Kuvalehti 27: 28-37.

Leppänen, Marko 2012:Esoteerinen maantiedeja periferiaterapia. Rajaton syli:taivas estetiikan, ylevän ja mielen peilinä. (Perjantai 5. lokakuuta 2012.) [online] < esoteerinenmaantiede. blogspot.fi/2012/10/>

Makota, Janina 1984: Nature as an Aesthetic Object. Perception of Nature in an Aesthetic Attitude. - Herausgegeben von Gerd Wolandt (in Zusammenarbeit mit Rudolf Lüthe und Stephan Nachtsheim), Die Ästhetik, das tägliche Leben und die Künste. 8. internationaler Kongress für Ästhetik. Ausgewählte Vorträge. Bonn: Bouvier Verlag Herbert Grundmann. 121-123.

Mäkelä, Matti 2001: Syrämmen kieli. Helsinki:WSOY.

Männikkö, Esko 2014: Esko Männikkö - Time Flies. Toim. Maija Koskinen \& Pirkko Tuukkanen. Helsinki: Suomen Taideyhdistys.

Paavolainen, Olavi 2012: Synkkä yksinpuhelu. Päiväkirjan lehtiä vuosilta 1941-1944. Helsinki: Otava.

Pekonen, Osmo (toim.) 2005: Elämän vuodenajat. Jyväskylä: Minerva.

Pitkänen, Matti A. 1975: Suomalaisia kuvia. Teksti: Raimo O. Kojo. Helsinki: Weilin+Göös.

Rapola, Martti 1971: Vaarin maisema. Uudistettu painos ynnä Omat maisemani. Helsinki: Otava.

Rautio, Pessi 2017: Luontosuhteemme taiteen kautta. - Emotionaalisesta mekanistiseen. Taide 3: 9-14.

Riukulehto, Sulevi 2012: Kotiseutu on kokonaisuus. Ruralia-instituutin blogi. 17.1.2012 [online] < http://blogs.helsinki.fi/hy-ruralia/2012/01/17/kotiseutu-on-kokonaisuus/ >

Sepänmaa, Yrjö 2014: Ihminen luontona, luonto ihmisenä. - Knuuttila, Seppo \& Ulla Piela (toim.), Ympäristömytologia. Helsinki: SKS. 21-33. 
Sepänmaa, Yrjö 2017: Sydämen maisema. - Vanhatalo, Riitta (toim.), Kotiseutu 2017. Helsinki: Suomen Kotiseutuliitto. 79-82.

Silvennoinen, Harri 2017: Maiseman kauneus ja metsänhoidon vaikutus koettuun maisemaan metsikkötasolla. Joensuu: Suomen Metsätieteellinen Seura, Helsingin yliopiston maatalous-metsätieteellinen tiedekunta ja Itä-Suomen yliopiston metsätieteiden osasto.

Taut, Bruno 2004: Alpine Architektur. Eine Utopie. / Alpine Architecture. A Utopia. New York: Prestel Publishing.

Vainio, Annina 2017: Ihmisvihaaja? - Helsingin Sanomat 17.8.2017, B 1-2.

Vainonen, Jyrki 2014: Askelia kotiseudulla. - Askelia. Kirjoituksia kävelemisestä. Helsinki: Basam Books. 25-40.

Varmavuori, Marjaana 2017: Lahokaviosammal uhkaa panna Helsingin rakentamissuunnitelmat uusiksi yli 10000 asukkaan uudessa kaupunginosassa. Helsingin Sanomat 26.7.2017.

Vartio, Marja-Liisa 1968: Alma käy kotona. - Parnasso 3: 146-151.

Viita, Lauri 1961: Suutarikin, suuri viisas. Runoa ja proosaa. Porvoo - Helsinki:WSOY.

Weisman, Alan 2008: Maailma ilman meitä. Suom. Ulla Lempinen \& Tiina Ohinmaa. Jyväskylä: Atena.

Wittgenstein, Ludwig 1981: Filosofisia tutkimuksia. Suom. Heikki Nyman. Porvoo-HelsinkiJuva:WSOY.

\section{Elokuvat}

Kim, Ki-duk 2003: Viisi vuodenaikaa. (Spring, Summer, Fall, Winter... and Spring.) Etelä-Korea, Saksa.

Kuivalainen, Anu 2017: Sielunmetsä. Helsinki: Filmimaa.

Suutari, Virpi 2014: Eedenistä pohjoiseen. Helsinki: Made Oy.

FT Yrjö Sepänmaa on ympäristöestetiikan emeritusprofessori Joensuun yliopistosta. 